which my own may give rise. I intended this when I began to be a private letter merely; but if you see fit to publish it, I have no objection, and 1 do not think my friend, Dr. Taylor, would have any.-I am, Sirs, your obedient servant, HENRY HAYMAN, D.D. Rector of Aldingham; Hon. Canon of Carlisle. Rector of Aldingh
Aldingham, Clrerston, Aug. 15th, 1887 .

\section{USEFUL EMPLOYMENT IN THE TREATMENT OF THE INSANE.}

To the Editors of THE LANCET.

Sirs,-I have read with much interest the article in your issue of Aug. 6th on the Lunacy Commissioners' report, and am grateful for the prominence you give to occupation as a cardinal point in the treatment of the insane. The Commissioners have, I think, done well to call attention specially to this point, and to express a hope that more attention may be paid to it as a potent remedial agency in the treatment of the insane.

It is pointed out in the report that "the employment of patients of the private class in hospitals and licensed houses is attended with greater difficulty than that of patients in county and borough asylums," and the case of St. Andrew's Hospital, Northampton, is quoted as a notable achievement, inasmuch as one-third of the gentlemen in that establishment are engaged in gardening and farm work. This is very creditable to the energetic medical superintendent of that asylum, as it is only during the past two or three years that he has had premises extensive enough to allow the development of the employment system.

I believe I may claim what little credit there may be in being the first to ventilate in the columns of the Journal of Mental Science the advantages of employment in the treatment of mental diseases in the upper classes, having written a paper on that subject for the Journal of July, 1882. For the encouragement of those medical proprietors and superintendents who may be afraid of the "much thought, trouble, and ingenuity" mentioned in the Commissioners' report, $I$ should like to state that I have found no reason to depart from the practice I adopted seven years ago of insisting on regular occupation for every able-bodied patient in my asylum, and that I have now not the slightest trouble in getting at least two-thirds of my gentlemen patients (i.e., all those who are physically fit for work) to engage in regular useful occupation, which percentage compares favourably with the average in county and borough asylums of $\frac{56}{100}$, or the "notable achievement" of St. Andrew's Hospital quoted above, where one-third of the male patients are employed. I am perhaps rather too enthusiastic on this subject, but $I$ firmly believe that it has only been found possible to abolish restraint and seclusion in English asylums, and the use of locked doors and airing courts in some Scotch asylums, by reason of the increased and intelligent interest betrayed on the part of asylam superintendents in the useful and rational employment of their patients.

I am, Sirs, your obedient servant, DAVID BowER, M.D.

Springfield House Asylum, Bedford, Aug. 11th, 1887.

\section{BJRACIC ACID AS A FOOD PRESERVATIVE,}

\section{To the Editor's of THE LANCET.}

SIRS,--The question regarding the use of borax and boracic acid as food preserratives, upon which a joint preliminary report, referred to in your issue of the 13th inst., was recently presented to the Kensington vestry by Dr. Dudfield and myself, arose through my having found boracic acid in a sample of potted cream submitted to me offeially for analysis, and subsequently in several samples of milk.

It is obrious that if the vendors of foods containing boracic acid are to be proceeded against under the Sale of Food and Drugs Act, the proceedings must be taken under the most severe sections of the Act-those, namely, which are intended to proride against the admixture of auy substance actually known to be injurious to bealth, or likely to be injurious to bealth, with articles of food; and it therefore becomes necessary to obtain definite evidence as to whether boracic acid and borax can or cannot be considered as injurious additions. Fery little information upon this head is torthcoming; but, as you very justly remark in your annotation, what little there is is very decidedly against the use of the drug. This, indeed, is the conclusion that one would naturally anticipate on a priori grounds, and 1 may perhaps say that in the early part of 1886, chiefly upon such grounds, I made some remarks in public against the use of boracic acid preservatives, which were subsequently reproduced in the Chemical News. ${ }^{1}$ In the report above referred to we did not think it necessary to give the full text of Dr. Förster's experiments and conclusions; but I am very glad that this has now been put before the readers of THE LANCET in Mr. Charles Hancock's excellent translation from Dingler's Joumal, for the matter is unquestionably one of great public interest and importance. The drug was present in smaller amount in the samples of milk than in the sample of potted cream above referred to. The latter, in fact, contained so much of it that its taste was very distinctly perceptible.

Finally, I venture to draw your especial attention to two passages in our joint report. They are as follows:--

"An eminent authority whom we have consulted refers to the tendency of these substances to set up diarrhœa, a disease very prevalent in hot weather, when the preservative is most used to prevent that change which milk and cream are apt to undergo, rapiàly, at a high atmospheric temperature."

"We desire to say, in conclusion, that, though in the present state of our knowledge the injurious action of very small doses of borax or boracic acid, even in the case of infants, and even having regard to the doses being continuous, may perhaps be considered as 'not proven,' it will probably become a question whether the use of any known preservative, in lieu of refrigeration, in any amount, however small, should not be prohibited, in view of possible and indeed probable abuse, and while doubt exists as to the action of the drug employed."

These remarks will, I believe, on consideration, be found tolerably suggestive.

$$
\text { I am, Sirs, yours faithfuily, }
$$

Charles E. Cassal,

Public Analyst for Kensington. St. George's, Hanoversquare, and High Wycombe.

Town Hall, Kensington, Aug. 16 th, 1887.

\section{"DISEASE AND MEDICAL ATTENDANCE AT WORKHOUSES." \\ To the Editors of THe LANCET.}

SIRS,-As there have lately been several letters in THe LANCET with regard to the question of admitting " a second medical opinion into the workhouse," my experience in this matter may perhaps interest your correspondents.

I am the resident medical officer of the Chorlton Union Hospital and Workhouse, Manchester, and in the male lunatic wards of the hospital there was some three or four years ago a patient suffering from dementia, and incurably insane. This patient's friends wished him to be removed from the workhouse to a private asylum, and they sent their own medical attendant to visit him in the workhouse. This gentleman, a qualified surgeon, saw the patient in the workhouse, examined him, and filled up the papers necessary for his removal to an asylum. He never communicated with me, and I knew absolutely nothing about the matter until after the patient was removed from the workhouse. I reported the matter at the time to the guardians, and the clerk to the guardians ruled that " a pauper, or the friends of any pauper, had a perfect right to send for any medical man, and such medical man bad a perfect right to treat such pauper in any way he pleased, without communicating with the medical officer of the workhouse at all." These were the exact words used by the clerk, which of course settled the matter.

August, 1887

I am, Sirs, yours obediently,

J. S. ORCHARD, M.D.

1 March 12th, 1886.

Manchester Water Supply.-In view of the rapidly-diminishing quantity of water in store at the Manchester Corporation reservoirs, the authorities have had their attention directed to the question of procuring a further supply from some flooded collieries at Moston, a village adjacent to the city. Samples of the water, which is stated to be of splendid quality and practically inexhaustible, hare been taken for analy sis. 